Lect. univ. dr. Bogdan Dima

Facultatea de Drept, Universitatea din București

Președinte al Asociației Centrul pentru Analize Strategice

\title{
득르
}

\section{Starea de urgență va fi constituțională sau nu va fi deloc}

Rezumat: în acest articol voi discuta două subiecte. În primul rând, voi explica jurisprudența Curții Constituționale cu privire la restrângerea exercițiului drepturilor și libertăților fundamentale prin intermediul ordonanțelor de urgență adoptate de Guvern. În al doilea rând, voi propune o anumită interpretare diferită a textelor constituționale care reglementează starea de urgență (art. 93), restrângerea exercițiului drepturilor și libertăților fundamentale (art. 53) și delegarea legislativă (art. 115).

Cuvinte cheie: stare de urgență, ordonanțe de urgență, restrângerea exercițiului unor drepturi și libertăți fundamentale

\section{State of Emergency Will Be Constitutional or It Will Not Be at All}

Abstract: In this article, I shall discuss two issues. First, I shall explain the Constitutional Court case-law on matters related to restrictions of fundamental rights and liberties by emergency decrees adopted by the Government. Second, I shall propose a specific and different interpretation of the constitutional provisions regulating the state of emergency (art. 93), the restriction of fundamental rights and liberties (art. 53) and the legislative delegation (art. 115).

Key words: state of emergency, emergency ordinances, restriction of fundamental rights and liberties

Adoptarea de către Președintele României a Decretului nr. 195/2020 privind instituirea stării de urgență pe teritoriul României ca urmare a situației epidemiologice cauzate de SARSCoV-2 ridică o serie de întrebări de ordin constituțional și legal care trebuie/ar trebui să fie cât mai bine clarificate și înțelese la nivelul societății.

Ordinea concretă reclamă acțiunea imediată și coroborată a autorităților statului și a membrilor comunității pentru eliminarea efectelor negative ale pandemiei. Instituirea stării de urgență reprezintă o măsură excepțională cu scopul de a proteja existența statului, înțeles ca sumă a trei elemente componente: populație, teritoriu și suveranitate. Această măsură excepțională nu se situează/nu trebuie să se situeze în afara ordinii constituționale și legale existente. De asemenea, măsurile efective dispuse de autoritățile publice în starea de urgență sunt în totalitate parte a ordinii constituționale și trebuie să respecte legislația în vigoare, tot așa 
cum cetățenii au responsabilitatea și obligația respectării normelor de comportament stabilite de autoritățile statului.

Sunt foarte multe subiecte de ordin juridic care pot fi discutate cu privire la starea de urgență. Însă, unul este cu adevărat esențial din perspectivă constituțională: Care sunt actele juridice prin pot fi restrânse drepturi și libertăți fundamentale în timpul stării de urgență?

Constituția oferă un răspuns în art. 53. Însă, lucrurile sunt mai complicate decât par la prima vedere. Conform Legii fundamentale, exerciţiul unor drepturi sau al unor libertăţi fundamentale poate fi restrâns numai prin lege şi numai dacă se impune, după caz, pentru: apărarea securităţii naţionale, a ordinii, a sănătăţii ori a moralei publice, a drepturilor şi a libertăţilor cetăţenilor; desfăşurarea instrucţiei penale; prevenirea consecinţelor unei calamităţi naturale, ale unui dezastru ori ale unui sinistru deosebit de grav. Mai mult, restrângerea poate fi dispusă numai dacă este necesară într-o societate democratică. Măsura trebuie să fie proporţională cu situaţia care a determinat-o, să fie aplicată în mod nediscriminatoriu şi fără a aduce atingere existenţei dreptului sau a libertăţii.

Nu voi analiza art. 53 din Constituție în complexitatea sa. Mă voi referi, în principal, la prima condiție de validitate a restrângerii exercițiului unor drepturi și libertăți, anume ca măsura să fie dispusă doar „prin lege”. Dar ce se înțelege prin lege în sensul art. 53 din Constituție? Ar putea fi ordonanța de urgență considerată o lege în sensul art. 53, prin care se poate restrânge exercițiul unor drepturi și libertăți în timpul stării de urgență instituite?

Curtea Constituțională a dezvoltat o întreagă jurisprudență care explică semnificația conceputului de „lege”, în funcție de distincția dintre criteriul formal/organic şi cel material. Potrivit criteriului formal/organic, legea este doar actul autorității legiuitoare, adică actul Parlamentului. Potrivit criteriului material, contează conținutul actului juridic, obiectul normei, respectiv relațiile sociale reglementate. În considerarea criteriului material, inclusiv ordonanțele de urgență ale Guvernului au putere de lege. Sunt considerate acte de reglementare primară, chiar dacă formal sunt adoptate de o autoritate a administrației publice, iar nu de autoritatea legiuitoare.

Însă, există și o jurisprudență mai recentă a Curții Constituționale cu privire la limitele prevăzute de Constituție prin raportare la conținutul ordonanțelor de urgență. în baza acestei jurisprudențe, ordonanțele de urgență nu pot să afecteze în sens negativ drepturile, libertățile și îndatoririle prevăzure de Constituție. În opinia Curții, a afecta în sens negativ înseamnă „a suprima”, „a aduce atingere”, „a prejudicia”, „a vătăma”, „a leza” sau „a antrena consecințe negative". Or, o dispoziție care restrânge exercițiul unui drept sau al unei libertăți prevăzute în Constituție, în mod evident constituie o afectare în sens negativ a respectivului drept sau libertăți. De exemplu, o ordonanță de urgență prin care s-ar dispune interzicerea circulației persoanelor între anumite ore sau în anumite locuri ar fi neconstituțională prin raportare la art. 115 alin. 6, întrucât afectează în mod negativ o libertate fundamentală a cetățeanului.

Așadar, dacă ne raportăm la jurisprudența Curții Constituționale, la dispozițiile art. 53, art. 115 alin. 6 și art. 93 alin. 1 din Constituție, precum și la dispozițiile art. 14 lit. d coroborat cu art. 4 din OUG nr. 1/1999, ar rezulta faptul că restrângerea unui drept sau a unei libertăți prevăzute 
de Legea fundamentală în timpul stării de urgență nu s-ar putea dispune decât prin lege a Parlamentului, nu și prin ordonanțe de urgență.

Însă, o astfel de interpretare este excesiv formalistă. Nu ține cont nici de semnificația textelor constituționale, de scopul acestora, dar nici de finalitatea urmărită de Curtea Constituțională în jurisprudența sa cu privire la afectarea prin ordonanțe de urgență a drepturilor și libertăților constituționale ale cetățenilor.

În stare de urgență instituită, legea cadru în materie (la care face trimitere însăși Constituția în art. 93 alin.1) permite adoptarea unor măsuri care au ca efect restrângerea exercițiului unor drepturi și libertăți. Scopul acestor măsuri este evitarea, îndepărtarea, diminuarea efectelor negative ale unor pericole grave, ale unui dezastru ori sinistru deosebit de grav care, dacă se perpetuează, vor ajunge să afecteze statul în toate componentele sale (populație, teritoriu și suveranitate). Dacă s-ar ajunge la o situație în care statul însuși nu mai este funcțional, atunci și exercițiul oricărui drept sau libertăți nu va mai putea fi garantat și protejat. Ca atare, unul dintre scopurile urmărite prin aplicarea, întotdeauna temporară, a măsurilor de restrângere a exercițiului unor drepturi și libertăți în situația excepțională a stării de urgență este salvgardarea pentru viitor a exercițiului deplin al respectivelor drepturi și libertăți.

Așadar, doar în timpul stării de urgență apare logic și necesar ca măsurile de restrângere a exercițiului unor drepturi și libertăți să poată fi dispuse nu numai prin lege, act al Parlamentului, ci și prin ordonanțe de urgență, desigur, numai în măsura în care sunt îndeplinite condițiile prevăzute la art. 53 din Constituție (de ex., măsura să fie proporțională cu situația care a determinat-o, să fie necesară într-o societate democratică și să aibă un scop definit clar - de ex., să fie instituită pentru apărarea sănătății publice sau pentru prevenirea consecințelor unei calamități sau a unui sinistru deosebit de grav).

În situația în care, în stare de urgență, aceste condiții prevăzute de art. 53 din Constituție sunt îndeplinite, restrângerea exercițiului unor drepturi și libertăți fundamentale prin ordonanță de urgență nu mai poate fi considerară o afectare în sens negativ a respectivelor drepturi și libertăți, tocmai pentru că scopul pentru care a fost instituită teporar răstrângerea este unul legitim, anume să asigure pentru viitor revenirea la exercițiului deplin al respectivelor drepturi și libertăți.

O astfel de interpretare asigură atât garanții pentru respectarea raporturilor constituționale dintre Guvern și Parlament (Parlamentul va putea verifica și va putea decide cu privire la conținutul acestor ordonanțe de urgență), cât și garanții că supremația Constituției nu va fi încălcată (se pot ridica excepții de neconstituționalitate cu privire la aceste ordonanțe de urgență, conform dispozițiilor constituționale și legale).

Nu în ultimul rând, pentru că starea de urgență instituită rămâne parte integrantă din ordinea constituțională și legală a statului, este necesar să cunoaștem care sunt garanțiile prevăzute împotriva posibilelor abuzuri ale autorităților publice în aplicarea măsurilor dispuse prin actele administrative emise pentru aplicarea stării de urgență.

În principal, actele administrative emise în temeiul OUG nr. 1/1999, dacă nu se încadrează în categoria celor care sunt exceptate în mod absolut de la controlul în contencios administrativ (actele de comandament cu caracter militar și actele autorităților în raporturile lor politice cu 
Parlamentul), pot fi atacate de către persoanele care se consideră vătămate în drepturile și interesele lor legitime de respectivele acte la instanțele de contencios administrativ. Temeiul legal al unei astfel de acțiuni este art. 5 alin. 3 din Legea contenciosului administrativ. $O$ astfel de măsură este posibilă pentru simplul motiv că cea mai mare parte a actelor administrative emise în temeiul OUG nr. 1/1999 se încadrează în categoria expres identificată de Legea contenciosului administrativ de acte administrative emise pentru aplicarea regimului stării de urgență. Astfel, pot fi atacate în fața instanțelor de contencios administrativ cu solicitarea de anulare, dar aplicarea lor nu poate fi suspendată de instanță (această soluție este cuprinsă în art. 5 alin. 3 din Legea contenciosului administrativ).

Cu alte cuvinte, legiuitorul a înțeles și a acceptat ideea că persoanele fizice și juridice trebuie protejate în fața unor posibile abuzuri și nelegalități din partea autorităților publice chemate să gestioneze starea de urgență. Din această perspectivă, dispozițiile art. 5 alin. 3 din Legea contenciosului administrativ dau sens și fac efective dispozițiile art. $3^{2}$ lit. $d$ din OUG nr. 1/1999, conform cărora, pe durata stării de urgență este interzisă restrângerea accesului liber la justiție.

În concluzie, deși starea de urgență are un regim juridic constituțional și legal profund derogatoriu, excepțional, rămâne în continuare parte componentă a ordinii constituționale și legale a statului român. Din acest motiv, statul, prin autoritățile sale, va avea nu numai atribuții de gestionare și eliminare a efectelor sociale, economice, sanitare și politice ale acestei situații epidemiologice nefaste, ci și obligația respectării și promovării principiului supremației Constituției și a legilor în vigoare. Privit din această perspectivă, titlul acestui articol capătă sens: starea de urgență va fi constituțională sau nu va fi de loc. Respectând cu toții garanțiile constituționale și legale ale ordinii constituționale nu vom ajunge la haos. Pentru că în haos, nicio normă legală nu se poate aplica, deci niciun comportament nu va mai fi previzibil.

Materialul a fost publicat pe G4media.ro ssi preluat ulterior în revista online a Facultăţii de Drept, AUBD - Forum juridic nr 1/2020. 